\title{
WHITE-METAL BEARING ALLOYS: MECHANICAL PROPERTIES AT DIFFERENT TEMPERATURES AND SERVICE TESTS
}

\author{
By Harry K. Herschman and John L. Basil
}

ABSTRACT

A study was made of the wear resistance and other mechanical properties of 11 white-metal bearing alloys. These included 2 tin-base and 8 lead-base alloys and 1 cadmium-zinc alloy. Each of the properties, with the exception of wear resistance was determined at several temperatures, ranging from $20^{\circ}$ to $200^{\circ} \mathrm{C}$. $\left(68^{\circ}\right.$ to $390^{\circ} \mathrm{F}$.). Resistance to wear was determined only at $20^{\circ} \mathrm{C}$. No one of the alloys tested was found to excel in all of the mechanical properties studied. Thus, the tin-base alloys showed higher resistance to wear and in most cases had higher Izod impact values, at each temperature of test, than the lead-base alloys, but in most cases, showed lower resistance to pounding than the lead-base and cadmium-zinc alloys. The hardness numbers and compressive properties of the tin-base alloys were found to be lower than those for the alkaline-metal hardened lead alloys and a cadmium-zinc alloy. The mechanical properties of the leadantimony-tin alloys were, in most cases, higher as the tin content was increased.

Crank-shaft bearings of four compositions were prepared for service tests in United States Army class B trucks. These compositions consisted of two tin-base and two lead-base alloys. The results of these tests indicated that the tin-base alloys were superior in their wear resistance to the lead-base alloys. These results were consistent with those obtained on wear in the laboratory tests.

The usual white-metal bearing alloys require in their composition tin or antimony or both. These elements are so-called "strategic" metals and the potential military demand for them is considerable. These facts were responsible for the sponsoring by the War Department of recent studies at the Bureau of Standards aimed toward the reduction or possible elimination of the amounts of tin and antimony needed for bearing metals.

One phase of this work was a study of white-metal bearing alloys with particular reference to the wear resistance and such other mechanical properties as appeared to be of chief significance in the service of such alloys in bearings. The compositions of the alloys studied appear in Table 1. A more complete discussion of the details and results of this investigation was presented in a paper ${ }^{1}$ before the June, 1932, meeting of the American Society for Testing Materials. Some additional work has since been completed. This included (1) a metallographic study of the alloys tested and (2) the determination of the mechanical properties of hardened lead B (Table 1).

1 H. K. Herschman and J. L. Basil, Mechanical Properties of White Metal Bearing Alloys at Different Temperatures, Proc. A. S. T. M., vol. 32 , pt. 2 , p. 536, 1932. 
TABLE 1.-Results of chemical analyses of white-metal bearing alloys

\begin{tabular}{|c|c|c|c|c|c|c|c|}
\hline Alloy designation & Lead & Tin & $\begin{array}{l}\text { Anti- } \\
\text { mony }\end{array}$ & Copper & $\begin{array}{c}\text { Cad- } \\
\text { mium }\end{array}$ & Zinc & Other constituents, per cent \\
\hline $\begin{array}{l}\text { No. 1 } \\
\text { No. } 3 \\
\text { No. } 6 \\
\text { No. } 7 \\
\text { No. } 8 \\
\text { No. } 10 \\
\text { No. } 11 \\
\text { Hardened lead }{ }^{1}{ }^{1} \\
\text { Hardened lead }{ }^{2} \\
\text { Cadmium-zine }{ }^{3} \\
\text { A }^{4}\end{array}$ & \begin{tabular}{|c|} 
Per cent \\
-12.3 \\
78.8 \\
79.7 \\
87.0 \\
88.1 \\
96.93 \\
98.0 \\
S0.6
\end{tabular} & \begin{tabular}{c} 
Per cent \\
90.9 \\
83.8 \\
20.8 \\
8.4 \\
5.0 \\
1.2 \\
\hdashline .18 \\
-1.8
\end{tabular} & $\begin{array}{r}\text { Per cent } \\
4.6 \\
8.1 \\
15.5 \\
12.8 \\
15.3 \\
11.8 \\
11.9 \\
-13.5\end{array}$ & $\begin{array}{c}\text { Per cent } \\
4.5 \\
8.1 \\
1.4 \\
-1\end{array}$ & \begin{tabular}{|r|} 
Per cent \\
\\
\\
\\
\end{tabular} & \begin{tabular}{|l} 
Per cent \\
\\
\end{tabular} & $\begin{array}{l}\mathrm{Hg} 0.33, \mathrm{Ba} 1.70, \mathrm{Ca} 0.70 . \\
\mathrm{Na} 0.65, \mathrm{~K} 0.3, \mathrm{Ca} 0.75, \mathrm{Li} 0.4 \text {. } \\
\text { Ni } 0.2, \text { As } 0.6 \text {. }\end{array}$ \\
\hline
\end{tabular}

1 Analysis by the National Lead Co.

2 Nominal composition as given by the Maywood Chemical Co.

3 Nominal composition.

- Analysis made by J. A. Scherrer, Bureau of Standards.

Each of the properties of the white-metal bearing alloys, with the exception of wear resistance, was determined at several temperatures ranging from $20^{\circ}$ to $200^{\circ} \mathrm{C}$. $\left(68^{\circ}\right.$ to $390^{\circ} \mathrm{F}$.), since it is in reality the properties at the higher temperatures that play the major part in determining the success or failure of a bearing metal under service conditions. The properties studied at these various temperatures included resistance to impact (Izod test) and to pounding (repeated impact), the strength in compression and Brinell hardness. Resistance to wear was determined only at $20^{\circ} \mathrm{C}$. In addition to the laboratory tests, which included those items above described, service tests were run on a series of crank-shaft bearings, prepared of four compositions, and installed in United States Army class B trucks. The compositions of these alloys are listed in Table 2.

TABLE 2.-Chemical composition of white-metal bearing alloys used in service tests

\begin{tabular}{|c|c|c|c|c|c|c|}
\hline Designation & Tin & Lead & Copper & $\begin{array}{l}\text { Anti- } \\
\text { mony }\end{array}$ & Barium & Calcium \\
\hline $\begin{array}{lll}A & 1 & \ldots \\
B & 2\end{array}$ & $\begin{array}{r}\text { Per cent } \\
90.48 \\
90.0 \\
3.27 \\
-\end{array}$ & $\begin{array}{c}\text { Per cent } \\
0.58 \\
82.52 \\
97.5\end{array}$ & $\begin{array}{c}\text { Per cent } \\
4.26 \\
10.0 \\
.15 \\
\end{array}$ & $\begin{array}{r}\text { Per cent } \\
4.69 \\
14.05\end{array}$ & $\begin{array}{l}\text { Per cent } \\
1.75\end{array}$ & $\begin{array}{l}\text { Per cent } \\
0.75\end{array}$ \\
\hline
\end{tabular}

${ }^{1}$ Analysis by the BohnjAluminum \& Bronze Co.

${ }^{2}$ Compositions are nominal values.

The wear test specimens were prepared by casting the white-metal alloy on the periphery of a bronze ring and were then finish machined. Resistance to wear was determined on the "universal Amsler wear testing machine" modified to permit testing under low loads and in the presence of kerosene.

The pounding, single-blow impact, and compression test specimens were chill cast, one-eighth inch oversize to allow for finish machining. The hardness specimens were chill-cast disks. The apparatus used in the pounding tests consisted essentially of a 2-pound hammer dropped through a distance of 2 inches on the specimen. The singleblow impact tests were made on an Izod impact machine of 120 footpound capacity. Brinell hardness numbers were determined with a 
Rockwell hardness testing machine equipped with a $10-\mathrm{mm}$ ball under a 60 -kg load. A Riehle 10,000-pound capacity tension-compression machine was employed for the compression tests. A special strain gage was designed for measuring the deformation of specimens under compression at elevated temperatures. Each apparatus described,

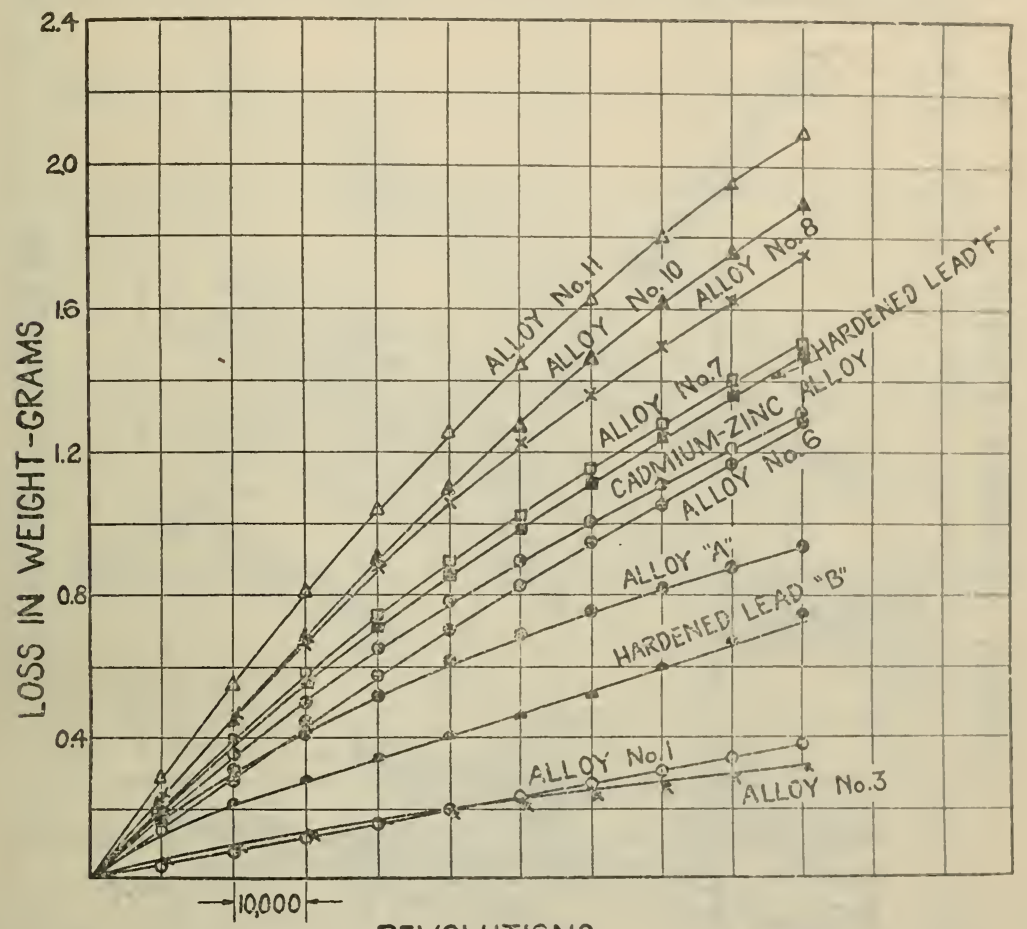

\section{REVOLUTIONS}

FIGURE 1.-Relation between wear and revolutions for white-metal bearing alloys tested on Amsler wear lesting machine

All alloys were tested against S. A. E. No. 1045 steel heat treated to give a Brinell hardness number of 240 .

with the exception of the Amsler wear machine, was equipped with a heating element to provide for the elevated temperature tests.

No one of the alloys considered was found to excel in all of the mechanical properties studied. Thus the tin-base alloys showed higher resistance to wear (fig. 1) and in most cases had higher Izod impact values (fig. 2) at each temperature of test than did the leadbase alloys. In most cases, however, the tin-base alloys showed lower 
resistance to pounding than the lead-base and cadmium-zinc alloys. The hardness number and the compressive properties (fig. 3) of the tin-base alloys were found to be lower than those of the cadmiumzinc alloys and of the hardened-lead alloys $\mathrm{F}$ and $\mathrm{B}$. The mechanical

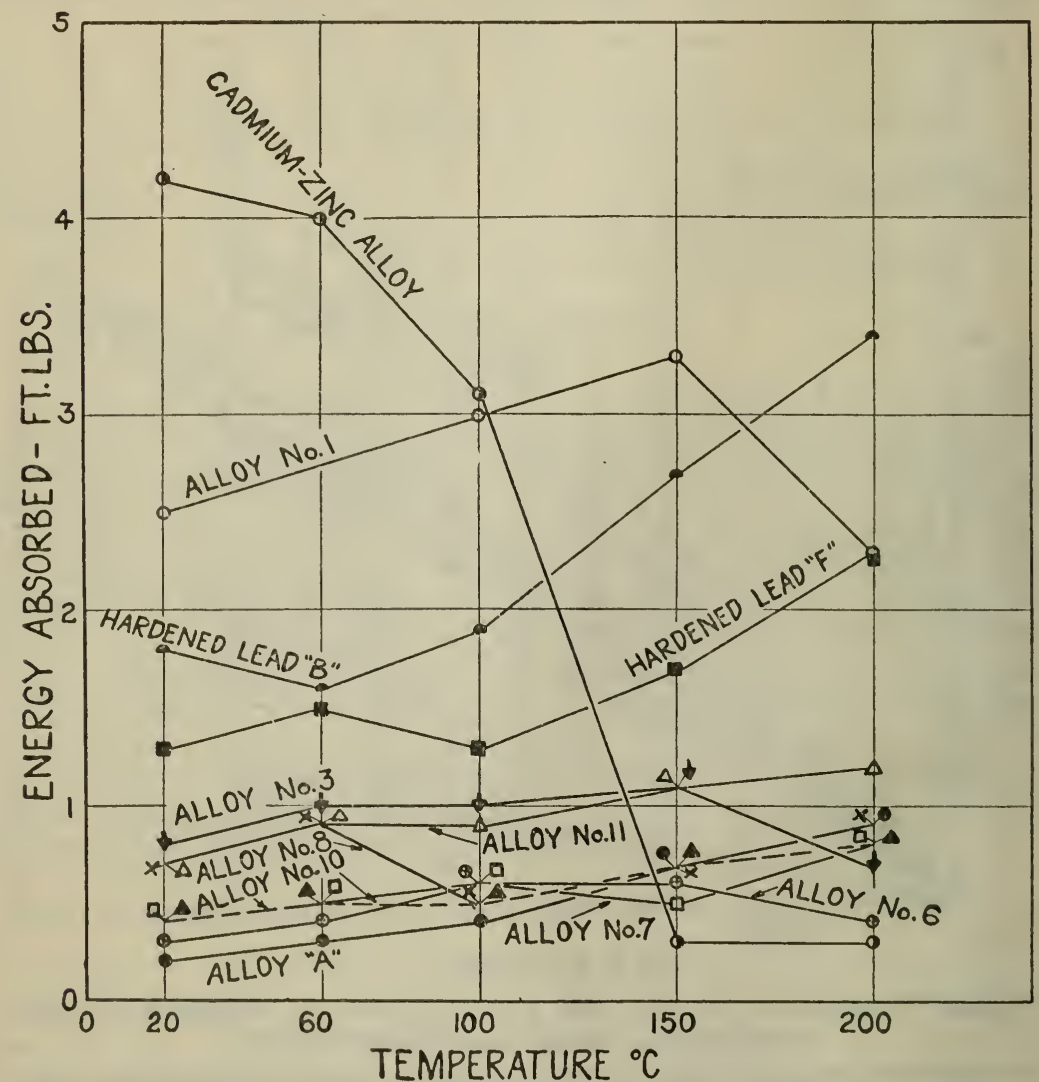

FIGURE 2.-Effect of temperature upon the impact resistance (Izod test) of white-metal bearing alloys

properties of the lead-antimony-tin alloys, in most cases, were higher as the tin content was increased.

The results obtained in the service tests showed that the tin-base alloys were superior in their wear resistance to both the hardened lead $\mathrm{F}$ and the lead-antimony-tin alloy containing about 3 per cent tin. These results were consistent with the laboratory results on wear. 
Acknowledgments are due to the following companies who cooperated in various phases of the work described: The Bunting Brass

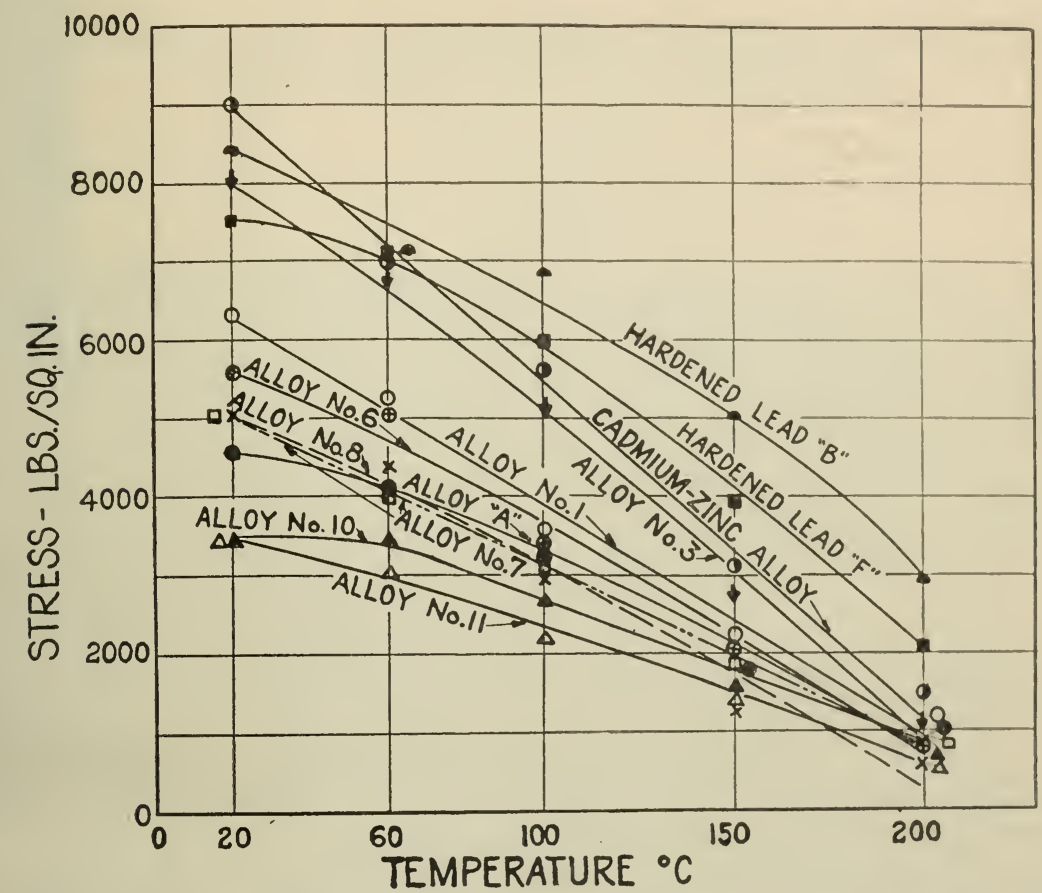

FIGURE 3.-Relation of compression stress, producing 0.3 per cent deformation, to temperature of test

\& Bronze Co., the National Lead Co., the Bohn Aluminum \& Bronze Co., and the Maywood Chemical Co.

Washington, October 8, 1932. 